\title{
Luciano Floridi: The Ethics of Information. Oxford: Oxford University Press, 2013, pp.357 + XIX. ISBN 978-0-19-964132-1
}

Polskiemu czytelnikowi tematyka, a nawet i samo pojęcie etyki informacyjnej (information ethics, IE) znane są raczej od niedawna. Wydaje się, że w polskim piśmiennictwie informatologicznym pierwszą publikacją, w której użyto terminu „etyka informacyjna” był artykuł Barbary Sosińskiej-Kalaty z 2003 r. ${ }^{1}$. W zasadzie pierwsza dekada XXI w. zapisała się w historii polskiej bibliologii i informatologii jako ta, w której do dyskursu naukowego w tej dyscyplinie i dyskusji w zawodowym środowisku bibliotekarzy i pracowników informacji powróciła sprawa etyki. Właśnie wtedy pojawiło się najwięcej publikacji o tematyce etycznej od czasów książki Zbigniewa Żmigrodzkiego z 1991 r., która była pierwszą polską monografią poświęconą etyce zawodowej bibliotekarzy². Przyczyniła się do tego zapewne konferencja „Bibliotekarz w świecie wartości”, zorganizowana w 2003 r. we Wrocławiu, której pokłosiem była publikacja pokonferencyjna ${ }^{3}$. Dyskusję nad problematyką etycznego wymiaru działalności bibliotecznej i informacyjnej podjęto także na ogólnopolskiej konferencji SBP nt. „Zawód bibliotekarza dziś i jutro”, zorganizowanej we wrześniu 2003 r., czego rezultatem stało się zorganizowanie przy Zarządzie Głównym SBP grupy roboczej, która w 2004 r. podjęła prace nad polskim kodeksem etyki zawodowej bibliotekarza i pracownika informacji. Rok później został on opublikowany nakładem Wydawnictwa SBP , a więc w 2015 r., 22 lutego, będziemy obchodzić 10-lecie przyjęcia przez polskie środowisko bibliotekarskie jego kodeksu etycznego. W ostatnich latach coraz więcej polskich badaczy podejmuje rozważania tematycznie wpisujące się w zakres etyki informacyjnej. Bardzo to cieszy, bo za granicą, zwłaszcza w USA, studia nad tą problematyką mają już dużą tradycję i bogate piśmiennictwo. Warto przypomnieć, że to właśnie w Stanach Zjednoczonych oraz w Niemczech, prawie równocześnie, w 1988 r. po raz pierwszy Robert Hauptman (USA) oraz Rafael Capurro (Niemcy) użyli terminu „etyka informacyjna” (ang. information ethics, niem. Informationsethik).

W piśmiennictwie zagranicznym obok terminu information ethics, który tłumaczymy jako etyka informacyjna, pojawia się także termin ethics of information, którego bezpośrednim przekładem jest wyrażenie „etyka informacji”. Do ukucia i funkcjonowania tego ostatniego terminu przyczynili się przede wszystkim przedstawiciele nauk filozoficznych, w dużej mierze autor recenzowanej tu książki - Luciano Floridi, którzy mówiąc o etycznych aspektach informacji, rozważania te zbierali pod ogólną nazwą ethics of information, analogicznie jak w przypadku: filozofii informacji (ang. philosophy of information), polityki informacji (ang. politics of information) czy logiki informacji (ang. logics of information). Czasami w literaturze przedmiotu dwa wspomniane powyżej terminy stosowane są zamiennie, jednak sytuacja taka spotykana jest już dość rzadko, gdyż obserwuje się tendencje dążące do ujednolicenia terminologii i nazewnictwa na rzecz information ethics.

Etyka informacyjna, którą badacze z nią związani starają się w ostatnich latach ukonstytuować jako odrębną dyscyplinę naukową, zajmuje się kwestiami etycznymi procesów związanych z „życiem” informacji (tj. obiegiem informacji w społeczeństwie - pozyskiwaniem, przetwarzaniem, opracowywaniem, przechowywaniem i udostępnianiem) oraz skutkami rozwoju i implementacji nowych

1 B. Sosińska-Kalata (2003). Etyka w nauce o informacji, Bibliotekarz, 9, 3-10.

2 Z. Żmigrodzki (1991). Problemy bibliotekarskiej etyki zawodowej. Katowice: UŚ.

3 S. Kubów (red.) (2003). Bibliotekarz w świecie wartości: materiały konferencji. Wrocław, 15-16 maja 2003 r. Wrocław: Dolnośląska Szkoła Wyższa Edukacji Towarzystwa Wiedzy Powszechnej.

${ }^{4}$ Kodeks etyki bibliotekarza i pracownika informacji (2005). Warszawa: Wydaw. SBP. 
technologii informacyjno-komunikacyjnych (ICT) ${ }^{5}$. Dorobek tak rozumianej etyki informacyjnej tworzą i wykorzystują specjaliści różnych dyscyplin, zarówno informacja naukowa i bibliotekoznawstwo, jak i dziennikarstwo, medioznawstwo, informatyka i cybernetyka, a także filozofia. Należy jednak zaznaczyć, że przedstawiony powyżej zestaw dyscyplin nie jest katalogiem zamkniętym, wskutek bowiem coraz szerszego wykorzystywania ICT w różnych obszarach życia i badań naukowych przedstawiciele coraz większej liczby specjalności naukowych zwracają swoje zainteresowania ku etycznym aspektom różnych zjawisk informacyjnych związanych z obszarem ich działalności badawczej, chociażby w medycynie i naukach o zdrowiu. Stąd coraz częściej w środowisku naukowym mówi się o potrzebie stworzenia globalnej, albo międzykuturowej etyki informacyjnej, która z jednej strony będzie uwzględniała i rozważała kwestie ważne dla wszystkich korzystających z ICT w skali światowej, a z drugiej - osadzała te kwestie w kontekście kulturowym, filozoficznym, społecznym i prawnym, wskazując podobieństwa i różnice oraz akcenty, na które kładzie się nacisk, w zależności od perspektywy rozważań podejmowanych w poszczególnych krajach lub kręgach kulturowych.

Luciano Floridi w recenzowanej książce proponuje spojrzenie na informację i kwestie z nią związane osadzone właśnie na gruncie filozofii i etyki. Dotyczy ona więc problematyki związanej z etyką informacyjną, rozumianą jako subdyscyplina filozoficzna, która korzystając z narzędzi, oferowanych jej przez filozofię i etykę, stara się odpowiedzieć na pytania o ontologię i podwaliny etyki informacyjnej, jej status na tle innych rodzajów etyki oraz innych dyscyplin naukowych, uniwersalny model, status moralny szeroko pojętych użytkowników informacji (zarówno ludzi, jak i maszyny), a także rozważa etykę informacyjną w kontekście teorii etycznych, zarówno historycznych, jak i współczesnych, szukając w nich odpowiedzi na kwestie nacechowane etycznie i dylematy moralne pojawiające się w związku z obiegiem informacji w społeczeństwie ${ }^{6}$. Książka została wydana w 2013 r. i jest pierwszą publikacją o charakterze monograficznym, która w całości poświęcona jest stricte filozoficznym rozważaniom nt. etyki informacyjnej. Życiorys naukowy jej autora jest bogaty i barwny, dlatego przytoczę tylko kilka najważniejszych informacji. Floridi jest profesorem filozofii i etyki informacji na Uniwersytecie Oksfordzkim w Anglii, a także na Uniwersytecie Amerykańskim w Waszyngtonie i członkiem wielu zespołów badawczych związanych z rozpoznaniem i opisaniem wpływu nowych technologii na społeczeństwo. Jego badania skupiają się na filozofii i etyce informacji, etyce informacyjnej i komputerowej, a także na filozofii technologii, którym poświęcił łącznie ponad 150 artykułów, przetłumaczonych na wiele języków, oraz kilka książek. The Ethics of Information jest przedostatnią książką Floridiego. W maju 2014 r. wydał kolejną monografię - The Fourth Revolution - How the infosphere is reshaping human reality ${ }^{7}$. Wcześniejsze książki Floridiego, które warto tu przypomnieć to The Philosophy of Information (2011), Information - A Very Short Introduction (2010) oraz The Cambridge Handbook of Information and Computer Ethics (2010). Niektóre z tych prac bezpośrednio, inne pośrednio są związane z tematem etyki informacyjnej. Warto też dodać, że autor postawił sobie za cel stworzenie tetralogii związanej z fenomenem informacji, a dwie spośród wspomnianych powyżej książek są jej częścią - pierwszą The Philosophy of Information, a drugą omawiana tu The Ethics of Information. Tetralogia oznacza dzieło złożone z czterech odrębnych, samoistnych prac, połączonych jednym tytułem ogólnym i tematyką (albo grupą postaci, zjawisk lub motywem przewodnim). Tetralogia

${ }^{5}$ Tak etykę informacyjną definiują np.: T. Carbo i S. Almagno (2001). Information Ethics: The Duty, Privilege and Challenge of Educating Information Professionals, Library Trends, 49(3), 510-518; Robert Hauptman czy Elizabeth Buchanan (zob. np.E.A. Buchanan \& K.A. Henderson (2009). Case studies in library and information science ethics. Jefferson; London: McFarland).

${ }^{6}$ Poza Floridim trudno znaleźć badaczy, którzy na gruncie filozofii i etyki tak dogłębnie analizują zjawisko informacji. Warto jednak wspomnieć nazwiska tych, których badania wpisują się w poświęcony tej tematyce dyskurs filozoficzny, np.: Rafael Capurro, Terry Bynum czy Charles Ess.

7 Ta ostatnia monografia Floridiego omówiona została przez prof.Jacka Wojciechowskiego w przeglądzie publikacji obcych (Wśród zagranicznych książek), który ukaże się w następnym numerze ZIN - 1/2015 [przyp. red.] 
Floridiego nosi tytuł Principia Philosophiae Informationis. Dwie kolejne jej części stanowić mają książki: The Politics of Information i The Logic of Information.

W pierwszej części tetralogii, czyli The Philosophy of Information, autor kładzie nacisk na rozpoznanie informacji jako nowego zjawiska badań, analizę konceptualnych podstaw informacji i zasad rządzących jej funkcjonowaniem, identyfikację zakresu pola badawczego filozofii informacji i charakteru mieszczących się w nim problemów, oraz analizę filozoficznych aspektów działalności informacyjno-komunikacyjnej. Analogicznie w książce The Ethics of Information rozbiera na czynniki pierwsze etykę informacyjną.

W szesnastu rozdziałach, których podstawę stanowi 39 artykułów, autorstwa samego Floridiego lub napisanych we współpracy z innymi badaczami, publikowanych od 1999 r. na łamach wielu czasopism, autor rozważa różne aspekty zmian następujących w życiu jednostek i całych społeczeństw pod wypływem rozwoju i upowszechnienia ICT. Kieruje uwagę czytelnika na związane z informacją zmiany zarówno w zakresie komunikacji, edukacji, pracy, środowiska, relacji społecznych, przemysłu i biznesu, jak i zdrowia oraz opieki zdrowotnej, a także konfliktów zbrojnych. Przeobrażenia tych sfer w związku z rozwojem ICT stanowią kwestie, które w prowadzonej współcześnie debacie etycznej, zajmują najwięcej miejsca. Etyka informacyjna skupia się w szczególności na zagadnieniach bezpieczeństwa w sieci oraz bezpieczeństwa danych osobowych, podziału cyfrowego i przepaści między społeczeństwami stechnicyzowanymi a niemającymi środków na rozwój w tym zakresie oraz prywatności i wolności słowa. Floridi poddaje te problemy rozważaniom za pomocą analizy dyskursu filozoficznego. Czasami rozważa również zjawiska jeszcze rzadko spotykane i słabo dotąd lub wcale nie opisane, albo wręcz hipotetyczne, ale według niego - możliwe w całkiem niedalekiej przyszłości, jak np. cyberwojny, gdzie bronią może być informacja, a także armie robotów, które na polach bitew miałyby zastąpić ludzi i tak jak gatunek ludzki umieć analizować informacje w czasie rzeczywistym, a następnie podejmować decyzje w sposób podobny do tego, jak czynią to ludzie.

W książce znajdziemy zarówno rozdziały o charakterze ogólnym, które służą wprowadzeniu pojęcia etyki informacyjnej i objaśnieniu związanych z nią kategorii pojęciowych i problemów badawczych, jak i rozdziały poświęcone refleksji filozoficznej i analizie etycznej konkretnych i bardzo szczegółowych zjawisk, związanych z rozwojem ICT. W dwóch pierwszych rozdziałach książki Floridi skupia uwagę na zjawisku rewolucji cyfrowej i informacyjnej, by wykazać, że dzisiaj to właśnie informacja staje się ekosystemem, w którym wszyscy funkcjonujemy. Wprowadza pojęcie „inforga” - organizm podłączony, sugerując, że współczesne autorowi pokolenie jest chyba ostatnim, które jeszcze potrafi żyć tylko i wyłącznie offline. Młodsze pokolenia zaczynają żyć i funkcjonować „hipertekstualnie”, jednocześnie off - i online. Autor, prowadząc czytelnika przez barwną i bardzo obrazową opowieść, których nie brak i w dalszej części książki, pisze o tym, jak roboty, czy nawet zwyczajna zmywarka poprzez fizyczną, w zasadzie ludzką, czynność zmywania naczyń, mogą przekraczać granice ludzkiego (jej użytkownika) świata. Podobnie człowiek poprzez cyfrowe interfejsy będzie przekraczał granice świata cyfrowego, aż w końcu stanie się inforgiem pośród innych (prawdopodobnie sztucznych) użytkowników infosfery. Z czasem, gdy najbardziej słyszalny będzie głos pokolenia digital natives, różnica między światem fizycznym a infosferą zatrze się, a nam - przedstawicielom pokoleń określanych za Markiem Prenskym mianem „digital immigrants”, będzie towarzyszyło uczucie zdeprymowania, wykluczenia, niepełnosprawności, a nawet psychicznej traumy, za każdym razem gdy nie będziemy włączeni w infosferę, jak w przypadku ryby pozostającej bez wody (s. 16). Pewnego dnia, zdaniem Floridiego, bycie inforgiem stanie się normalnością.

Następnie autor analizuje etykę informacyjną jako etykę źródeł informacji, produktów informacyjnych, środowiska informacyjnego, by na końcu przedstawić ją jako makroetykę infosfery (używa tutaj określenia e-nvironmental ethics), w której świat danych, informacji i wiedzy oraz cykle ich

${ }^{8}$ M. Prensky (2001). Digital Natives, Digital Immigrants. Part 1. On the Horizon 9 (5), 1-6; Digital Natives, Digital Immigrants. Part 2: Do They really think differently? On the Horizon 9 (6), 1-6; 
życia powinny być zorganizowane tak, by ułatwiać człowiekowi właściwe funkcjonowanie w infosferze. Kwestie tak rozumianej etyki informacyjnej szerzej omówione są w rozdziale czwartym, gdzie Floridi zastanawia się nad jej fundamentami, ewolucją i związkami z etyką komputerową. Zestawia ją z innymi teoriami etycznymi - etyką cnót, deontologią i konsekwencjalizmem oraz niestandardowymi teoriami, sugerując, że etykę informacyjną - wspieraną etyką komputerową - można uznać za pełnowartościową makroetykę. W rozdziale piątym, kontynuuje rozważania nad fundamentami etyki informacyjnej. Poświęca go etyce komputerowej (computer ethics, CE), prowadząc czytelnika poprzez różne wobec niej podejścia: negowanie jej naukowego charakteru, traktowanie jako etyki zawodowej, odrębnej dyscypliny czy jako etyki stosowanej, proponując na końcu innowacyjne podejście (innovative), w myśl którego etyka informacyjna stanowić ma fundament dla etyki komputerowej. Wydaje się, że można uznać to także za nawiązanie do prowadzonej na początku XXI w. na łamach międzynarodowych czasopism naukowych dyskusji o statusie etyki komputerowej i na fali tego - również etyki informacyjnej ${ }^{9}$. W tym miejscu warto przypomnieć też wydaną w $2008 \mathrm{r}$. książkę Wojciecha Bobera Powinność w świecie cyfrowym. Etyka komputerowa w świetle wspótczesnej filozofi moralnej ${ }^{10}$, w której w odniesieniu do etyki komputerowej poruszone zostały kwestie podobne do dyskutowanych przez Floridiego.

W kolejnym, szóstym, rozdziale Floridi zastanawia się nad wartością wewnętrzną infosfery, po to, by pokazać jak wielka jest rola informacji dla samej etyki i przeprowadzić aksjologiczną analizę informacji i infosfery samych w sobie. Rozdział konkluduje stwierdzeniem, że etyka informacyjna dowiedzie swojej wartości tylko wówczas, gdy jej zastosowania będą rodziły owoce. O tych zastosowaniach szerzej pisze autor w rozdziałach 11-14, poruszając w nich np. znaczenie ICT dla konstytuowania się ,ja”, podejmując ontologiczną interpretację prywatności informacji oraz dystrybucji moralności w infosferze, a także pokazując związki i wartość etyki informacyjnej i etyki biznesu. Autor rozważania o prywatności informacji poprzedza analizą wpływu ICT na jednostkę ludzką - to, jak ta jednostka postrzega i buduje samą siebie i swój obraz w oczach innych. Nawiązując do Platona, który omawiał wpływ wynalezienia pisma na przemiany ludzkości, Floridi dowodzi, że współczesna technologia Informacyjna i komunikacyjna działa z siłą nieporównywalnie większą niż siła oddziaływania pisma. Argumentuje, że ICT wzmacnia ludzką cielesność, zwiększa możliwości i siłę ludzkiego poznania oraz poszerza świadomość. W kontekście nowych technologii Floridi przygląda się kwestiom obecności, przestrzeni, czasu, wspomnień i percepcji. Filozoficzną interpretacją rozwija takie stwierdzenia jak to, że dzięki nowym technologiom nasze „ja”, choć jest w mózgu zlokalizowane, to niekoniecznie w nim jest obecne; że dzięki ICT przestajemy mieć konkretny wiek (informacje o nas, które się nie starzeją); że ICT pozwala nam chronić wspomnienia przed zapomnieniem (choć zapominanie to też sztuka kształtowania siebie); oraz że dzisiaj osobowe „Kim jestem dla ciebie?” wypierane jest przez bezosobowe „Kim jestem online?”. W tym kontekście zwraca uwagę na to, jak ważna jest prywatność i ochrona informacji, wzbogacając analizę o myśl spoza zachodniego kręgu kulturowego, rozważając indywidualizm i antropologię, a także zakres i ograniczenia prywatności informacji w dobie współczesnych ICT.

W pominiętym do tej pory w niniejszej recenzji rozdziale siódmym Floridi zajmuje się moralnością innych niż ludzie uczestników infosfery, cyfrowych lub społecznych, np. firm, partii, systemów hybrydowych itd. Sugeruje, że etyka informacyjna powiększyła grupę podmiotów moralnych o nowe

${ }^{9}$ Np. K. E. Himma (2003). The relationship between the uniqueness of computer ethics and its independence as a discipline in applied ethics. Ethics and Information Technology, 5(4), 225-237; czy T. Bynum (2008). Computer and information ethics.; A. P. Carlin (2003). Disciplinary debates and bases of interdisciplinary studies: The place of research ethics in library and information science. Library $\mathcal{E}$ information science research, 25(1), 3-18;

${ }_{10}$ W. J. Bober (2008). Powinność w świecie cyfrowym: etyka komputerowa w świetle wspótczesnej filozofi moralnej. Warszawa: Wydaw. Akademickie i Profesjonalne. 
jednostki, stawiając tym samym przed sobą wielkie wyzwania. Refleksja etyczna musi bowiem objąć również strefę zwaną przez Floridiego mindless morality („moralność bez-umysłowych”). W kolejnych rozdziałach często wraca do kwestii uczestników infosfery i roli oraz miejsca poszczególnych podmiotów moralnych w etyce informacyjnej. W rozdziale piętnastym, gdzie Floridi rozważa etykę informacyjną w odniesieniu do zjawiska globalizacji, znów nawiązuje do rozdziału siódmego i następujących po nim, analizując konsekwencje, jakie dla dystrybucji moralności i podmiotów działań moralnych niesie przekształcenie infosfery w jeden, wielki i globalny ekosystemem.

Ostatni, szesnasty rozdział książki Floridi poświęca dyskusji z dwudziestoma odmiennymi, według niego błędnymi, interpretacjami etyki informacyjnej oraz zarzutami wobec niej formułowanymi. Dyskutuje z obecnymi w piśmiennictwie opiniami, że np. etyka informacyjna jest wyłącznie etyką newsów, krótkich tekstów i plików komputerowych; że jest zbyt upraszczająca, nieantropocentryczna, nieaplikowalna, supererogatoryjna i hipermoralistyczna; polemizuje z poglądami tych, którzy twierdzą z kolei, że jest zbyt konserwatywna i panteistyczna. Odpowiada na argumenty przeciwników uznania innych, poza ludźmi, użytkowników infosfery za autonomiczne podmioty moralne oraz tych, którzy nie zgadzają się z uniwersalnym charakterem etyki informacyjnej. Takie zakończenie rozważań pobudza do refleksji i systematyzuje wiedzę przedstawioną w książce.

Monografia etyki informacyjnej Luciano Floridiego jest napisana wartkim językiem, podejmuje kwestie bardzo aktualne, wokół których istnieje wiele kontrowersyjnych opinii. Czyta się ją więc z wielką ciekawością, choć czasami potrzebny jest również i dystans, np. gdy autor snuje wizje na temat przyszłości ICT, funkcjonowania infosfery i jej użytkowników. Etyka informacyjna dzięki tej książce być może stanie się dla czytelników - parafrazując słowa L. Floridiego z epilogu - mniej niż przed jej lekturą difficult to find and hard to reach.

Monika Halasz-Cysarz Instytut Informacji Naukowej i Studiów Bibliologicznych Uniwersytet Warszawski

Nadestano: 02.12.2014. 